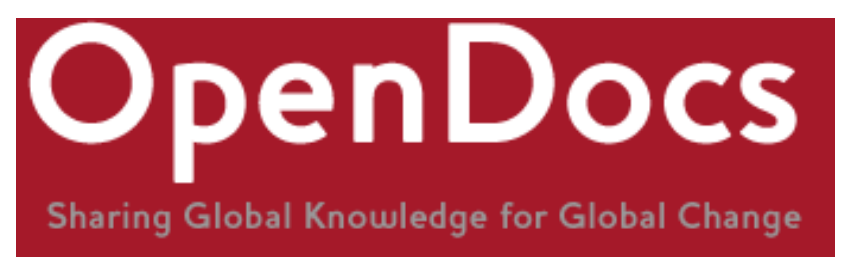

Title: Imagining a Silicon Savannah? Technological and Conceptual Connectivity in Kenya's BPO and Software Development Sectors.

Citation: Graham, M. and Mann, L. (2013) Imagining a Silicon Savannah? Technological and Conceptual Connectivity in Kenya's BPO and Software Development Sectors. The Electronic Journal of Information Systems in Developing Countries 56 (2) pp. 1-19.

Official URL: http://www.ejisdc.org/ojs2/index.php/ejisdc/article/view/1107

More details/abstract: This is a paper about expectations surrounding a potentially highly transformative moment in East Africa's history: the arrival of underwater fibre-optic broadband communications cables into the Indian Ocean port of Mombasa. It combines a media content analysis with findings from interviews with business owners in Kenya's nascent business process outsourcing (BPO) and software development sectors in order to explore how such moments of technological 'connectivity' are imagined, marketed and enacted within economic development. It argues that connectivity is not just a matter of boosting physical/material capacity but also about redressing conceptual connectivity; bringing places 'closer together' involves rehabilitating the images of places in peoples' minds and removing imagined senses of distance. As such, technologies of connectivity are marketed not just as tools of altered communications affordances, but more importantly, as momentary opportunities for revisiting the image of places from afar. Additionally, the cables reveal the importance of fostering internal linkages in order to better build international recognition and connections. 'Moments of expectation' that surround new ICT technologies reveal how discourse and representation play a strong role in enabling markets to form and change. The very idea of 'connectivity' itself is driving plans and policies throughout the region.

Version: Published version.

Terms of use: This journal provides open access to all of its content on the principle that making research freely available to the public supports a greater global exchange of knowledge. Such access is associated with increased readership and increased citation of an author's work. For more information on this approach, see the Public Knowledge Project, which has designed this system to improve the scholarly and public quality of research, and which freely distributes the journal system as well as other software to support the open access publishing of scholarly resources.

This is a download from OpenDocs at the Institute of Development Studies

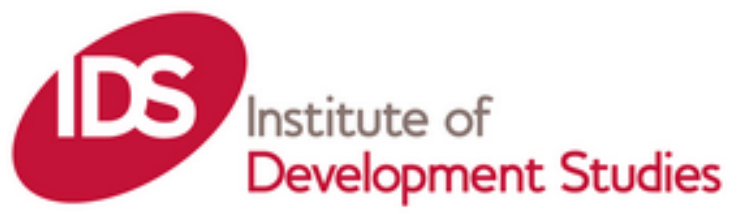




\title{
IMAgINING A Silicon SAVANNAH? TECHNOLOGICAL AND CONCEPTUAL CONNECTIVITY IN KENYA'S BPO AND SOFTWARE DEVELOPMENT SECTORS
}

\author{
Mark Graham \\ Oxford Internet Institute \\ School of Geography and the Environment \\ University of Oxford \\ UK \\ mark.graham@oii.ox.ac.uk
}

\author{
Laura Mann \\ Oxford Internet Institute \\ University of Oxford \\ UK \\ $\underline{\text { laura.mann@oii.ox.ac.uk }}^{1}$
}

\begin{abstract}
This is a paper about expectations surrounding a potentially highly transformative moment in East Africa's history: the arrival of underwater fibre-optic broadband communications cables into the Indian Ocean port of Mombasa. It combines a media content analysis with findings from interviews with business owners in Kenya's nascent business process outsourcing (BPO) and software development sectors in order to explore how such moments of technological 'connectivity' are imagined, marketed and enacted within economic development. It argues that connectivity is not just a matter of boosting physical/material capacity but also about redressing conceptual connectivity; bringing places 'closer together' involves rehabilitating the images of places in peoples' minds and removing imagined senses of distance. As such, technologies of connectivity are marketed not just as tools of altered communications affordances, but more importantly, as momentary opportunities for revisiting the image of places from afar. Additionally, the cables reveal the importance of fostering internal linkages in order to better build international recognition and connections. 'Moments of expectation' that surround new ICT technologies reveal how discourse and representation play a strong role in enabling markets to form and change. The very idea of 'connectivity' itself is driving plans and policies throughout the region.

“The great historical tragedy of Africa has been not so much that it was too late in making contact with the rest of the world, as the manner in which that contact was brought about”
\end{abstract}

Aimé Césaire, Discourse on Colonialism, 1950 (1997): 226.

\section{INTRODUCTION: AN IMPORTANT ARRIVAL}

Contemporary digital communications are primarily made possible through fibre optic cables that span the globe and connect almost all populated places with one another. They are the conduit for the vast majority of international internet communication, voice calls and data

\footnotetext{
${ }^{1}$ This work was supported by grants from the British Academy, the John Fell Fund, and the ESRC/DFID. We also wish to thank Isis Hjorth, Dorothea Kleine, Jim Murphy, Casper Andersen, Olga Morawczynski and Padraig Carmody for their helpful input, feedback and suggestions.
} 
transmission. Yet, until the summer of 2009, there was only one major region of the planet that remained disconnected from this global network: East Africa ${ }^{2}$.

Until this time, East Africa had recorded extremely low rates of ICT access and use (Etta and Parvyn-wamahiu, 2003; Thioune, 2003). Furthermore the region had some of the highest data costs in the world due to the heavy reliance on satellite connections, which were both much slower and more expensive than connections elsewhere in the world. This all changed in July of 2009, when the first of four cables landed in Mombassa, Kenya and Dar es Salam, Tanzania (see Figure 1). The four cables, which cost over one billion US dollars to construct, were financed through a combination of private investment and public-private partnerships and are part of a scheme to develop ICT-related industries like Business Processes Outsourcing $\left(\mathrm{BPO}^{3}\right)$ and software development in the region.

SeaCom, the company that backed the cables, promoted their arrival as bringing a future in which "Africa [is] connected to the world". Such a claim, of course, implies that Africa was previously disconnected. As scholars of African history have all too well established, Africa has been 'connected' to the rest of the world for a very long time, albeit within an international framework of unequal economic and political power and within a philosophical framework in which the image and positionality of Africa and Africans has been reflected through a prism of 'Otherness' and difference from the West (Mudimbe, 1988; Bayart, 2000; Lovejoy, 2011). Moreover, connectivity with the outside world has been channeled through state elites who have tended to monopolize opportunities within the economy through their control of the state and its resources (Cooper, 1997; 2002; See also Allen, 1995)The pressing question is not whether or not Africa is connected to the rest of the world, but how and under what circumstances that connectivity is achieved and sustained. More broadly, does high-speed internet represent a 'novel' form of connectivity that can challenge entrenched patterns of elite extraversion and international dependence (Bayart, 2000; Cooper, 1997) or do ICT optimists in Africa suffer from historical amnesia on issues of connectivity?

As evidenced by the movements of Pan-Africanism in the 1960s and by more recent, market-orientated attempts to encourage an 'African renaissance' and a New Partnership for African Development (NEPAD), leaders on the continent have long recognized that there are not just structural, geographical or technological barriers that separate them from global circulations of wealth and power, but also conceptual and representational barriers that limit their ability to influence their positions within the international system (Ajulu, 2001). This article explores attempts to re-define such conceptual connectivity at a more micro level: within the ICT and business process outsourcing (BPO) sector of Kenya. We focus on these particular sectors of the economy because of both their relevance to the perceived radical transformation in Kenya's communications infrastructure and their departure from traditional economic priorities in the country.

2 Until 2009, East Africa was forced to rely on satellites for all international connectivity: making Internet access slower and more expensive than in the rest of the world.

3 For the remainder of this paper, we use "BPO" to refer to information processing and software development work that is performed as service for other companies. In other words, the term is employed to refer to a range of work from digital sweatshops doing highlight repetitive tasks to innovative and creative software development. 
Figure 1: Africa's Undersea Cables in 2009 and 2012

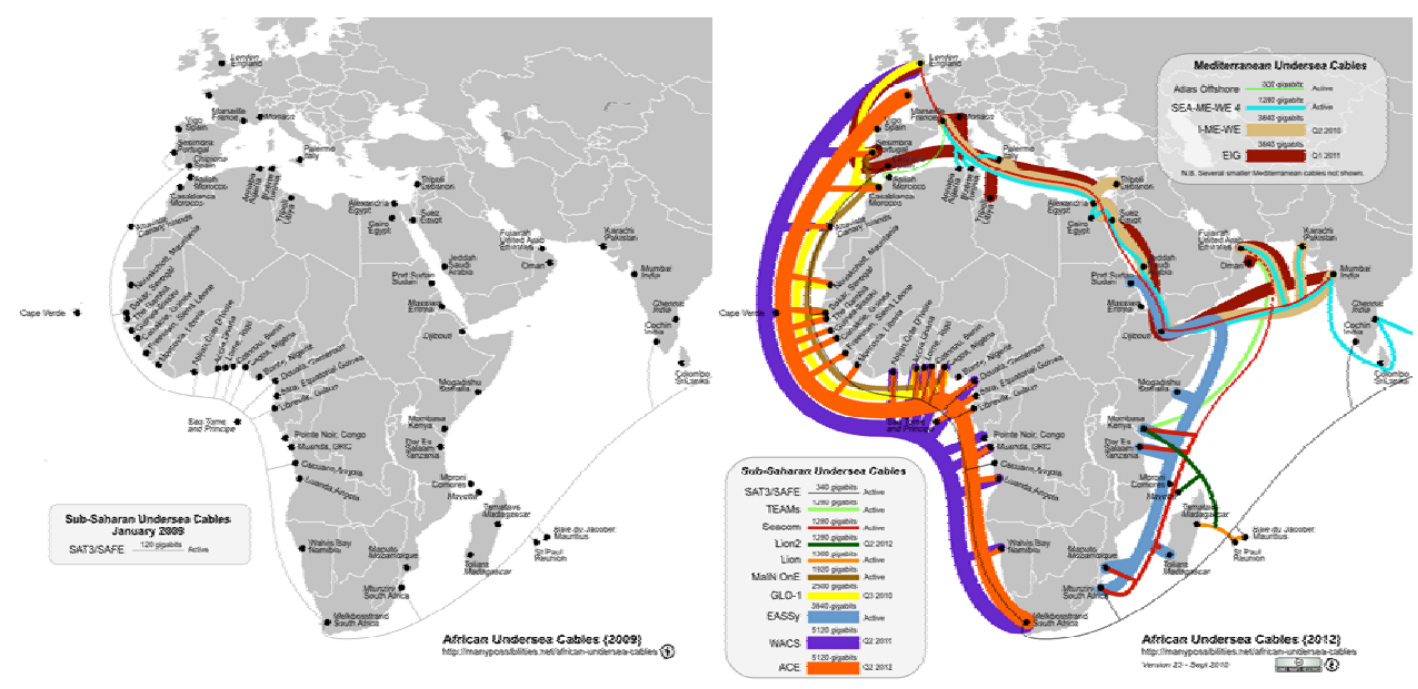

The paper draws on material from four sources: (1) interviews conducted in 2010 with twenty managers of BPO and software firms based in Nairobi; (2) a qualitative content analysis of 378 international and East African media reports of the landing of the cables; and (3) an analysis of Kenya's national development plan (Vision 2030) and surrounding documents and speeches. This varied material will demonstrate how the expectations surrounding the cables have played a strong role in allowing a new industry to form and grow. While the role of optimism is entrenched in the way we think about financial markets (Galbraith, 1954; de Meza and Southey, 1996; Akerlof and Shiller, 2009) ), it has largely been neglected in discussions of development in Africa. To many in Kenya today, the cables and the broader 'ICT revolution' thought to be happening on the continent represent an opportunity to use internet mediated representations to enact change in the imaginations of others.

\section{RE-IMAGINING GEOGRAPHIES OF REPRESENTATION}

While previous technological revolutions (like the Green Revolution) were enabled by a material chemistry, it is partly a conceptual chemistry that underpins enactions and understandings of the contemporary 'ICT Revolution'. On the one hand, much online life involves self-representation- the careful construction of ourselves and our businesses through articulated images and words- but on the other hand, the internet is also a repository of information about ourselves that others have disclosed, produced and occasionally, falsified. It is a chemistry that we cannot completely control for it combines public and private in new ways (Sveningsson, 2008).

When dealing with unfamiliar firms online, we often look for clues about the validity and authenticity of their claims: Who is this company? How can I trust them? We might search for evidence of an offline presence, a building or other traces that connects it to institutions or people that we recognize. We search for common associations, testimonies from others, evidence that demonstrates that this company with whom we deal is not merely a phantom of self-representation, but a real entity located in a 'real world'. At the same time, we may use the internet in reverse, as a tool to validate offline claims (Orgad, 2008). Our online and offline presences are interwoven in a chemistry of representation. 
In other words, we cannot discard the disadvantages we face in our offline lives just because we "go online". They remain. Nor do we interpret others with clean slates. Former associations and prejudices cloud our appraisals of online others. We should not think of internet connectivity as a binary of a disembedded online and an embedded offline life, but something that infuses life and seeps between online and offline spaces (Markham, 1998; Wellman and Haythornwaite, 2002).

Economies are not just sites and networks of information transmission but also imagined and cognitive spaces where people form beliefs about the authority and value of information. ICTs not only change the pace and flow of information transmission, they also shape the way in which information is produced and evaluated. Moreover, representations and associations also impact the way in which actors interpret and trust different streams of information. Some scholars have referred to these intermediating influences as 'sociocognitive prostheses' in that they allow individuals to understand and interpret the information they receive through use of extra cognitive 'limbs' (Caliskan and Callon, 2009 and 2010). In other words, our cognition is distributed between our own minds and the environments in which we think and operate (Callon and Law, 1995; Callon, Millo and Muniesa, 2007).

Africa has not had an easy time in Western imaginations. Images of the continent have been marred by narratives of conflict and poverty blasted from news reports, NGO advertisements, grim economic reports and occasionally, tragic Hollywood films (Achebe, 1977; Mudimbe, 1988; Fair, 1993; Wainaina, 2005). Many consider the continent a 'dangerous place', one deserving of pity or charity, but not one that readily excites anticipations of growth and profit among investors. As the economist, Elizabeth Asiedu writes:

"Countries in SSA (Sub-Saharan Africa) have on average received less FDI than countries in other regions by virtue of their geographical locationthere is a negative effect on FDI for being an African country. The negative and significant estimated coefficient of the Africa dummy suggests that there may be adverse regional effect for SSA. There are two plausible explanations for this. First, the continent is perceived as being inherently risky. This perception of Africa is supported by the empirical evidence of Haque, Nelson and Mathieson (2000), who find that commercial risk-rating agencies often rate African countries as riskier than warranted by the fundamentals. Second, due to lack of knowledge about countries in the continent, investment decisions are often not guided by country-specific conditions but rather based on inferences from the environment of neighbouring countries. Thus, to some extent, foreign investors evaluate African countries as if the countries in the continent constitute "one big country” (Asiedu, 2002: 114).

Accordingly, African entrepreneurs and creators face an uphill battle to redress this representation and garner better linkages, investment and trade for themselves (Bonsu, 2009; Nworah, 2006).

In recent years, African leaders and businesspeople have attempted to employ marketing and place-branding expertise, often through online portals, to better control and commodify the identities and images of their nations abroad. Existing research on such strategies has tended to focus on government websites and on government-led place-branding 
strategies. For example, Nworah explores the Nigerian government's Heart of Africa Image Project to redress the negative image of Nigerians online in light of 419 e-mail scams (Nworah, 2006). Fürsich and Robins have similarly conducted a content analysis of 29 African government websites to "explore how dominant structures within particular nations assert their role in the global imagined community” (Fürsich and Robins, 2002). They describe how the discourse "oscillates between motifs of modernity coded as capitalist progress (links to investment opportunities, tourism and national achievements) and as tradition (links to historic descriptions and tribal differentiation, with images of the premodern life, and nature and wildlife as signifiers)" (Fürsich and Robins, 2002: 196). The use of primordial identity as a "commercialized identity to be sold to global interests" (Fürsich and Robins, 2002: 206) is strongly echoed in John and Jean Comaroff's study of commercialised identities in ethno-businesses in South Africa (Comaroff and Comaroff, 2009). Such online representations are not dissimilar from the representations depicted in older analogue forms of media like stamps, currencies and newspaper advertisements.

While such studies of online branding demonstrate that the growth of the internet by no means diminishes negative (or simplified) stereotypes of Africa abroad nor necessarily undermines the dominance of national and tribal gatekeepers in the integration of economic identities and positionalities into the global system, the focus on top-down strategies, hides those of other businesses and entrepreneurs who might suffer from association with these 'primordial' identities and may use the internet for alternative representations. It is not just governments that are engaged in place-branding and representations, but individual actors as well. In contrast to the perception held of 419 scammers or the naturalized tribes on tourism or government sites, it would appear that, at least for however long the delicate balance of optimism lasts, many Kenyan ICT firms are seizing hold of the opportunity to re-invent a more positive conceptual connectivity for themselves and thereby re-define their positions within a global geography of representation.

\section{An EVOLVING Vision OF CoNNECTIVITY}

At first glance, Kenya might seem an unlikely destination for a thriving ICT sector: it is in the bottom quintile of the UN's Human Development Index and is beset by serious economic, social and political problems and struggles with a crumbling infrastructure. According to the World Bank (2011), the number of power outages in Kenya in a typical month is 6.9 and over a quarter of Kenyan firms identify the availability of electricity as a major constraint facing their businesses.

The BPO sector in Kenya employs only about 4,000 people and accounts for less than $0.01 \%$ of GDP (Republic of Kenya, 2007a; Omondi, 2012). ${ }^{4}$ This figure compares poorly with India's corresponding figure of 5.2\% (Waema, 2009). Despite this low number, Vision 2030, the Kenyan government's national development plan ${ }^{5}$, argues that the country should reduce its dependence on traditional agricultural commodities and focus more intently on the export of services (Kenyan ICT Board, 2009). The sector has therefore been set out as one of the six pillars of economic growth.

4 No current official statistics are available on the number of people employed in the Kenyan BPO sector. In 2007, the government put the figure at 3,500. More recent estimates by journalists and analysts suggest the number has reached 4,000.

5 Vision 2030 is currently being implemented through a series of five year development plans that a semi autonomous government agency oversees in collaboration with all relevant government departments and ministries.

The Electronic Journal of Information Systems in Developing Countries www.ejisdc.org 
Plans specifically call for up to 20,000 BPO jobs and sales of about 120 million US dollars per annum by 2012 (Republic of Kenya, 2007a; Omondi, 2012). Such growth would make BPO the country's fourth biggest export after horticulture, tea and tourism and would promote the sector, in the words of Vision 2030 as the "sector of choice employment among youth and young professionals” (Republic of Kenya, 2007a: 81).

For the planners behind Vision 2030, the arrival of fibre-optic cables represented the spark that would ignite this economic transformation. These expectations were further amplified and reproduced by media reporting on the arrival of the cables in the year after their landing. In both Kenyan and international stories and reports, there was a palpable sense of optimism and a taken-for-grantedness about the economic boost that faster internet connections would bring about, often stated in bold and powerful terms.

For instance, thirty two articles in our content analysis used the world "revolution" to frame the landing of the cables (e.g. the Sunday Independent's, June 14, 2010 reports "Fasten your seatbelts for the internet speed revolution"), whilst only fifteen of the news reports raised any sort of critical reflection about this link between connectivity and economic growth (e.g. constraints due to relatively low literacy rates, unreliable electricity supply, shortage of skills and local content, and rigid regulatory regimes). The BPO sector, in particular was singled out as the prime source of economic growth, with more than $10 \%$ (37) of the articles specifically identifying BPO as the most obvious area for growth.

This optimism was also reflected in 2010 interviews with business managers. While many managers recognized that the cables would not allow them to overcome all the issues they faced (access, pricing, speed, vandalism, electricity, etc.), they drew on similar narratives of how connectivity offered, not just incremental, but transformative, change. For instance, the manager of Iavi, David Mark, described how:

the reality is a lot [was] possible but now you have people motivated and less frustrated when they use the internet because of the speed... it's not a binary thing where those things weren't possible before the cable- but yeah, it's an idea that 'Oh yeah, you know, in Kenya, we've solved that internet problem.

Joseph Koch of Samnet, a Web services company, echoed this idea:

There has been so much buzz about the cables that everybody understands... they were going to change the country and you know there was a lot of buzz. And it gets people to go out and try and explore internet connectivity... And then it opens the possibilities- it opens people's minds into, you know, as to what is possible.

Such expectations were also frequently expressed within the contexts of upgrading and reconfigured value chains. Mugendi Nguru, the director of KenyaTweets.com, talking about his experiences before the cables, recalled: "without faster internet, you're landlocked. You can only do small projects.” Guy Curtis of Brand Africa similarly explained:

I can get a client in Britain as much as a bigger company can get a client in Britain. So I find the barriers ... are no longer there, because internet has made that the world to get global village [sic].

It might appear that these journalists and managers had simply been swept away by the unrealistic expectations marketed by the internet providers themselves during the time of radically changing connectivities in Kenya. A more pessimistic reading of connectivity might

The Electronic Journal of Information Systems in Developing Countries www.ejisdc.org 
acknowledge that broadband connectivity involves accelerating interdependence with domestic and foreign technology providers (Cline-cole and Powell 2004; Ya'u 2004). Even for those 'sector of choice' workers employed in BPO work, the long-term picture is far from ideal; the comparative advantage of much BPO work lies in flexible, low cost labour performing repetitive, outsourced tasks like basic customer care and data entry. In other words, upgrading East Africa's connection to the world is not a one-off technological acquisition, but rather a commitment to continually renew and deepen that connection (and potential vulnerability) in the future.

While much research has repeatedly demonstrated that the internet cannot eliminate the frictions of distance, bring into being a "global village" or serve as a panacea for development (e.g. Graham, 2008; 2011; 2013), this paper will demonstrate that the idealism surrounding the cables nevertheless produced distinct consequences. Exaggerated assumptions about the potentials of the internet are not only continuously repeated, but work as a powerful driving force shaping a range of business plans and strategies. As such, connectivity should not be understood chiefly as physical link that can be mediated through technological intervention. Rather technologies of connectivity, like the cables, are represented not just as tools of altered communications affordances, but more importantly, as momentary opportunities for redefining the image of places from afar. The next section will describe two clusters of expectations that have formed as a result of the arrival of the cables. It will contrast these two strategies and will reveal the mutually enhancing relationship between international and domestic forms of connectivity.

\section{CLUSTERS OF EXPECTATION}

Research has emphasized the role of inter-firm networks and clusters as resources through which African producers can build better international comparative advantages and thereby carve out stronger positionalities on the world stage (Mccormick, 1999; Murphy, 2007). Such clusters have been shown to facilitate trust, encourage innovation and knowledge transfer, concentrate lobbying attention on policy-makers and garner better market access to goods and services in international markets. However, as Murphy writes:

[i]n African cities... industrial clusters remain poorly developed and unsupported by most states. Where clusters have emerged, they have benefited primarily local markets, been organized by informal sector firms, exploited only pecuniary and labor pooling advantages, and have not exhibited what Bell and Albu (1999) term the "knowledge-changing" capabilities needed to facilitate a shift to higher-value and/or more globally desirable products (Murphy, 2007: 1758).

This section shows how the expectations surrounding the cables have generated two kinds of clustering strategies that may overcome these limitations. It will critically analyze these two strategies taking into account of both the potential of alliances to influence Kenya's international position in an international division of labour and the potential of clusters to harness the synergetic properties of networks to stimulate innovation and knowledge sharing.

Vision 2030 specifically calls for attracting a cluster of large international companies. Released in 2007, it states that: "This will be done by attracting at least 5 major leading IT suppliers, at least 10 large multinational companies and global BPO players to Kenya” (Republic of Kenya, 2007b: 14). At the time of research, the Kenyan government hoped to attract these companies to Kenya through the construction of a clustering 'technocity' in 
Malili $^{6}$, in an area that is sixty kilometers outside of the capital Nairobi but only eleven minutes from its international airport on a planned train link (Mark, 2011). Through publicprivate partnerships, the Kenyan government invested 17 million USD in the project (Muli, 2010). As Samuel Poghisio, the Minister of Information and Communication puts it:

The technopolois development leverages Kenya's unique status as a cultural, political, economic and transportation hub for Eastern Africa to lead the region in joining the Global Information Economy (quoted in China Daily, 2010).

From the point of view of Vision 2030, a niche had initially been targeted: customercare and voice services performed at a large scale and for a low cost (e.g. for airlines or banks) (Kenya ICT Board 2010). ${ }^{7}$ There was thus more of a concern that poverty was exacerbated by lack of access to markets (Marker et. al. 2002) than an attempt to upgrade into more advantageous value chain positions. Disconnection was understood principally as matter of geographical and technological isolation, and the government sought to bridge this gap through the development of a formal 'international hub'.

Interestingly, this approach contrasts sharply with the strategies of smaller Nairobibased companies engaging in social media work, software development, web design, mobile application development, IT consulting, Web mapping, and various other information processing, design and development tasks. Many of these firms use one of Nairobi's five innovation clusters ('iHub,' 'Nailab,' 'Fablab,' ‘iLab’ and the Human IPO’s Start-up Garage) as focal points. The largest of these incubators is the cluster focused around the iHub.

The iHub was set up in 2010 and quickly turned into an important part of Nairobi's BPO and software sectors. The building consists of a large open space with desk spaces, free high-speed internet access and a range of meeting and social spaces (see figure 2). The centre's physical space is supplemented with a variety of online spaces and networks (i.e. a blog, email list, Twitter feed, and Facebook group) that attempt to foster a sense of community around regular events (e.g. hackathons ${ }^{8}$, invited talks and parties) held both in the iHub and elsewhere in Nairobi. While clusters and face-to-face interaction are important elements in any regional development plan (Bathelt et al, 2004; Florida, 2002; Martin and Sunley, 2003; Storper and Venebles, 2004), a sharp contrast is apparent between the government's technocity far from the hustle and bustle of Nairobi's traffic but connected to its international airport and the i-Hub, set within the everyday environment of the city. These two very different forms of connectivities are also embodied in their different value chain strategies. While the proposed technocity was originally intended to focus on low-end outsourcing work like data entry and call-centres (essentially turning Malili into a digital export processing zone), the i-hub was built precisely to foster activities that would allow for both domestic generativity and, in many cases, upgraded value chain positions.

The growth of informal networks, fostered knowledge sharing and business collaboration at the i-hub, has been impressive. As of March 2011, the centre had over 3,000 members. Over 1000 of those members are software developers, and about 900 are designers.

6 The plans for the technocity display a gleaming golden city of skyscrapers surrounded by parks and lakes.

7 This targetting is also being performed through tax breaks (Waema 2005) and the adjustment of curricula in all Kenyan universities to "deliver basic BPO skills" (Kenya ICT Board 2010).

8A hackathon is a short and intense period of collaboration on code or software.

The Electronic Journal of Information Systems in Developing Countries www.ejisdc.org 
Importantly, at least twelve companies have already been formed through connections made in the iHub and three companies have found funding through investors that have used the iHub as a place to specifically find startup firms. ${ }^{9}$

The example of iHub makes it hard to deny that there is a strong culture of innovation in Kenya's ICT industry. From our sample of interviews, it appears that most of the firms that cluster around Nairobi's innovation hubs are recent and only consist of a few employees (in other words, they are stereotypical high tech startup companies). Many of the firms interviewed in 2010 were founded specifically to take advantage of the arrival of the new fibre-optic cables, knowing that the possibilities for work would greatly expand in a postcable landing environment and every respondent interviewed (irrespective of whether the arrival of the fibre-optic cables had any influence on why they decided to begin operations) indicated that faster internet connections have now become essential to the ways in which they conduct their business, in terms of information gathering, communications and sales.

\section{Figure 2: The Nairobi iHub}

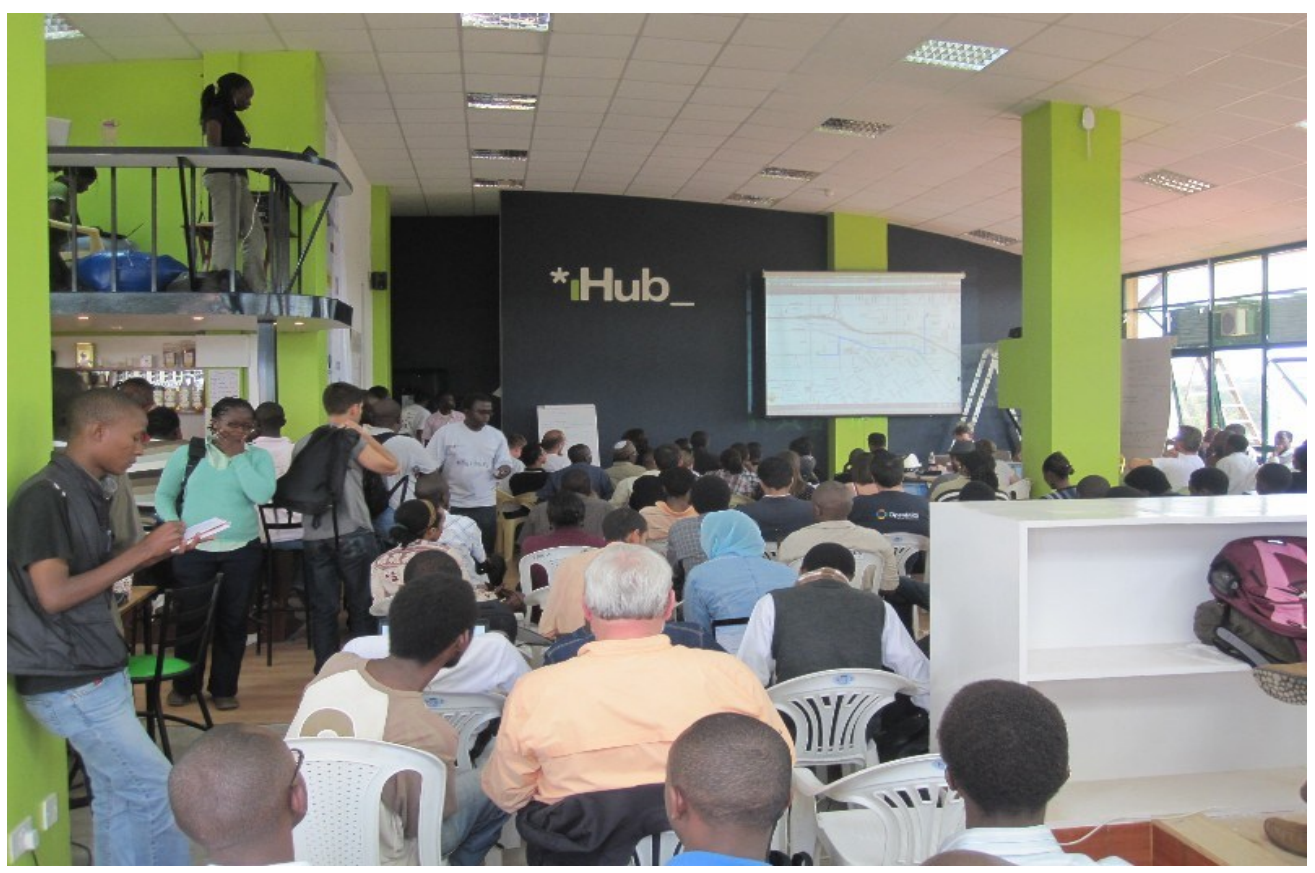

These companies and entrepreneurs had, until recently, been left outside of the official plans of the Kenyan government. As mentioned, Vision 2030 focused on low-end outsourcing work (like data entry and call-centres), and attempted to 'just be there' in the BPO industry. Nevertheless, in recent years, the government seems to have adapted its focus in order to accommodate this alternative vision of connectivity.

At the Connected Kenya 2012 Summit, the government announced a new National ICT master plan that would seek to place Kenya among the top 10 ICT hubs in the world (Wafula, 2012). According to the Kenyan Information and Communication Permanent Secretary, Bitange Ndemo:

9 According to Erik Hersman (2011), there are a total of 3,036 members in the iHub community. 
We are looking at having about 500 medium sized companies, the size of Sevenseas Technologies, and 20 multinational companies. We already are on the way of having the first multinational company in Ushahidi, as soon as it can get a way to monetise its services (quoted in Wafula, 2012).

The new plans hope to expand ICT's contribution to the country's GDP to about 25 per cent (Wafula, 2012). The Kenyan ICT Board has also introduced the Tandaa Digital Grant, setting aside eighty eight million USD in World Bank grants to stimulate local software developers. In its second year, in 2012, the fund awarded 30 grants to techpreneurs. Signalling the change of approach, Ndemo commented:

We have moved from discussing infrastructure to policy, content and capacity building in the industry. We need applications that can be able to offer Kenyans solutions and help us create internal efficiencies. By so doing we will save the economy billions of shillings (quoted in KICT, 2012).

Both public and private sector actors are investing huge amounts of money in plans framed by a powerful discourse that faster internet connectivity will bring about powerful economic changes. Furthermore, these expectations are encouraging the focusing of energies in two different clusters, one led by the government and one led by the private sector, but both buoyant on optimism. As a result of the growth of centres like i-hub and the success of many local developers, the government itself seems to have amended its understanding of connectivity from one concerned with a lack of access to markets to one concerned with a more conceptual understanding that challenges both internal forms of connectivity and Kenya's place in a global division of labour. At the same time, the development of centres like the i-hub signal alternative forms of international connectivity that challenge the prominence of states in mediating opportunity within the Kenyan economy. The final section will present two detailed case studies of the Kenyan firms, Horizon and Verviant, which have attempted to use the conceptual connectivity generated by the cables to fundamentally challenge the representation of their businesses and the wider Kenyan economy.

\section{CASE STUdies: HoRIZON AND VERVIANT}

Horizon is a company that was founded specifically to take advantage of the arrival of the fibre-optic cables. The company sits close to Nairobi's international airport overlooking a national park (see figure 3) ${ }^{10}$. The company does a variety of back office and contact centre work, with a particular focus on transcriptions and call centre operations for UK-based companies.

As of late 2010, they employed 180 employees doing around-the-clock work, but their facility allows them to quickly scale up to 1500 call centre seats in the event of a larger contract. In many ways, therefore, Horizon, is a perfect case for the type of firm that the government hopes to encourage as part of its Vision 2030 plans.

Horizon's CEO, Sanjay Sikka stressed that infrastructure could no longer be considered a major constraint since the arrival of the fibre-optic cables. The company is currently sited in a secure business park and would be a candidate for the move into the Malili technocity. They have two redundant power generators, and physically and logically redundant fibre links to ensure almost always-on connectivity.

10 The CEO of the company speculated that Horizon was probably the only contact centre in the world from which employees could see giraffes and elephants out of their windows.

The Electronic Journal of Information Systems in Developing Countries www.ejisdc.org 
Figure 3: Horizon Contact Centre Main office on Mombasa Rd., Nairobi

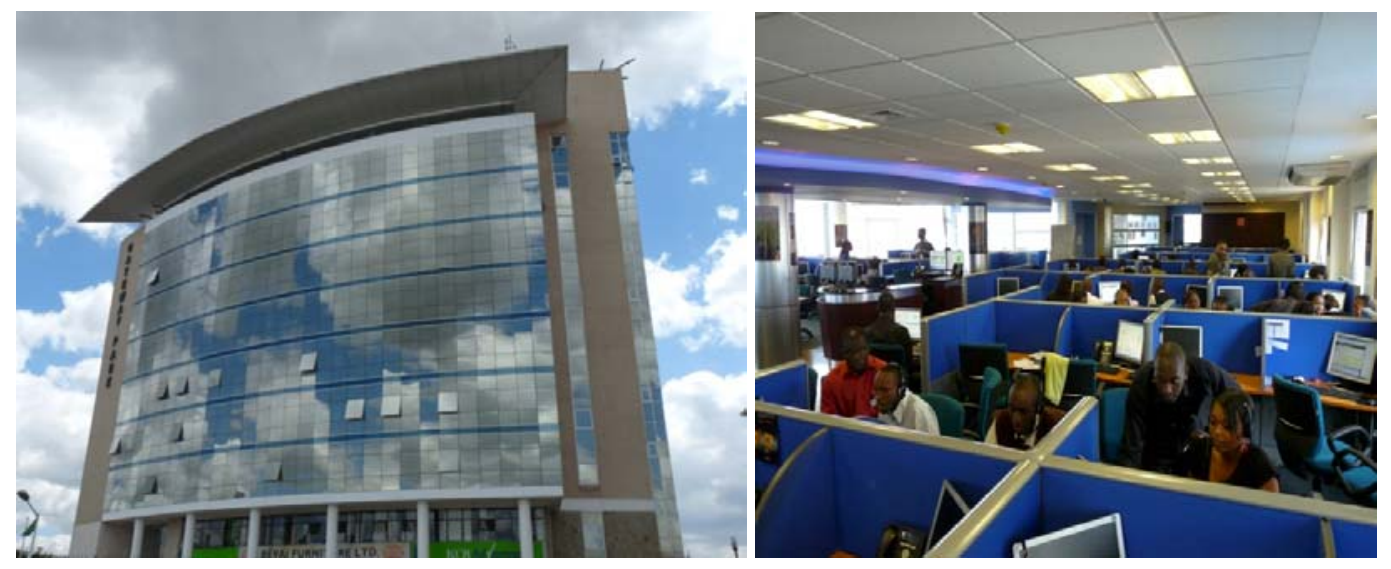

Mr. Sikka felt that the most significant constraint faced by the Kenyan BPO industry was not poor infrastructure but rather the widespread belief (from both within and outside of the country) that developing a viable technology sector in the country was unrealistic. For instance, when asked what some of the key barriers to the growth of Horizon are, Mr. Sikka, claimed that:

The biggest barrier is the fact that, like I said, Kenya is not perceived as a future BPO destination... there is a lot of negativity around political stability, safety, crime rate, and I think those are detrimental.

it has a lot to do with the image...when we were building our website, one of the things I wanted to put was a virtual tour of the facility where I wanted people to-when I say, "This is who we are," people go to the website, they click on our building... people may have a vague-somebody who has not been here will have a very different image... I don't know what it is like over there.

But he believed that the arrival of the cables had done much to change those perceptions:

The fiber optic has made it a connected world... it's far easier to sell outsourcing to an overseas client. It's important to have confidence when you are talking to overseas customers, and thereby that feeling of connectivity, you are a connected world, you are no longer isolated, one country within Africa, the Dark Continent, so on and so forth. It's important to overcome that feeling.

Similarly, when speaking more directly about his own firm, he observed:

When you have an organization in, say, UK or US, when they're thinking of outsourcing to us, and suddenly they say, "You don't even have fibre in this country." You will never be hired. You're not in the same place as the others. So I think [the fibre-optic cables] puts you in that same league.

There remained concerns that "a lot that needs to be done for [the BPO sector] in terms of putting it on the global map,” but overall Mr. Sikka believed that a more level playing field had now been established, and that Kenyan firms like his could use their perceived competitive advantages (price, similar time zone to markets, cultural similarities) to gain international outsourcing work. In other words, one of the most significant benefits of the 
cables for Horizon was a conceptual: the fact that "confidence obviously comes in when you are connected, when you feel you're a part of the global economy."

The second company, Verviant operates under a significantly different business model from Horizon. The company employs a relatively small number of staff (24 employees) and perform both on-demand Web development, software design, and mobile application development as well as creating their own software and IT platforms that they attempt to market to other companies (see figure 4). Verviant was founded in 2007 and began with a sole focus on outsourcing work. They initially struggled working with slow internet speeds, but ultimately were able to run their business through a $128 \mathrm{k}$ connection (this speed is only one half of the 2006 OECD definition of broadband). ${ }^{11}$

\section{Figure 4: Screenshot of Verviant's website}

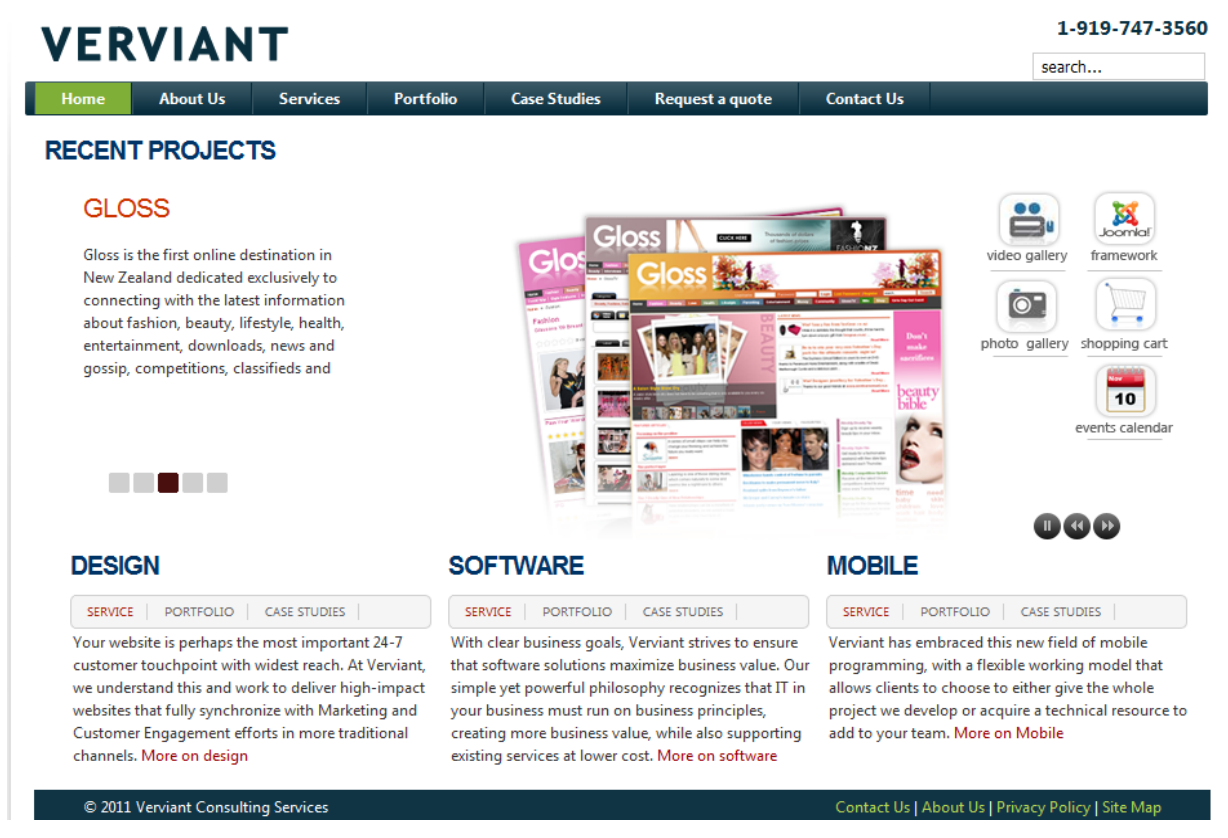

The CEO, Agosta Liko, explained that with such a slow connection "you couldn't do YouTube, you couldn't download music, you couldn't do a lot of video stuff," but that his company still got business because "we'll be cheaper than a typical First World provider. [Clients] make it work because we give good work at a good price.”

More recently, prices for faster internet speeds have dropped dramatically. The company currently has internet speeds that are twenty times faster than the bandwidth available four years ago (and was, furthermore, contemplating doubling those speeds in the near future). Mr. Liko explained that the increase in internet speeds has undoubtedly had an important effect on his business:

now when I make my calls on Skype, so the business changes ... an upload that used to take two hours, it's taking ten minutes. When we were remoting through a satellite and all that stuff, you used to type what is essential, you wait, but now you can work in real time.

11 OECD, 2006

The Electronic Journal of Information Systems in Developing Countries www.ejisdc.org 
The company sees its opportunity in doing work for what they call third-tier European and American companies. In other words, instead of targeting large multinationals that already have well-defined outsourcing strategies, they instead try to foster more intimate relationships with smaller companies (or IT consultants for those companies) that may have previously had only limited experience with outsourcing. Some of this work is done through existing contacts, but most is obtained though intermediate platforms like Guru.com and Elance.com. The company also performs a variety of software development that isn't specifically commissioned by clients: a sign of innovation and generativity absent from many of Kenya's contact centres.

One example of Verviant's work is the PesaPal project: a mobile payment platform that attempts to merge the highly popular M-Pesa mobile banking system with a web-based interface like PayPal. The tool therefore aims to disintermediate (by providing the consumer electronic payment infrastructure for) many financial transactions (a significant challenge in a country where most people do not have bank accounts) in Kenya in a way that should result in faster and more reliable movements of capital.

Unsurprisingly, Mr. Liko explained that reliable and fast broadband connections had amplified their ability to do work for clients abroad: "I can work from Kenya and now they [customers abroad] will never feel that this guy is in Kenya. That's pretty powerful.”

Liko explained that they have traditionally faced a general unwillingness on the part of many potential customers to outsource work to Kenya, noting that:

The first year of business was really tough. We told people, “I’m in Kenya,” they tell you, "Okay, cool, yeah, your product is good, and everything, but let me talk to other providers, then I'll talk to you." They're worried. You think Kenya is Ethiopia. You think Kenya is Rwanda, you know, people think Africa is a big country. One big country, and that's the perception. I lived in the States, and many people could not believe I speak English, they tell you-“'You've learned English so fast” [laughter]

It's always going to be an obstacle. Look, when you tell someone, 'I'm taking my software project to a company in Africa,' there's something wrong with that sentence. We're not known for software. Yet...

But the good thing about life right now, is that with that fiber optic cable, when Microsoft releases software, at midnight Pacific, I'm getting it before someone on the East Coast because they are asleep. Because midnight Pacific is 8am here. When Apple releases software, we're getting it the same day, so [no more] "Oh, we're bringing these people to teach the Africans," I have the internet. I can learn. I can play with it.

The traditional unwillingness of many clients to deal with African firms had meant that many of the intermediaries that Verviant transacted through ensured that the end customer never actually realises that their software or website was developed in Kenya. However, Liko hopes that the altered connectivity of the country will help foster a new sense of confidence, allowing the sector to start building stronger reputations: "So it's a thing where you grow slowly. Now even Kenyans themselves are convinced that they're known for software”.

Verviant starkly illustrates that the possibilities within the Kenyan BPO sector for business practices significantly different from the contact-centre work performed by Horizon 
and encouraged in government plans and strategies. Nevertheless, both CEOs maintain that one of the chief constraints traditionally facing their businesses was not the presence of physical distance or disconnection, but rather, a general reluctance on the part of foreign investors to do business with Kenya as an imagined place.

But the cables, rather than being seen as a mere communication affordance, were being used to redress the conceptual connectivity of Kenya in the imaginations of such clients. The presence of a reliable and faster internet connection appears to be allowing Kenyan firms the opportunity to demonstrate a wider display of competence and capability. Thus the case of Kenyan BPO reveals something wider about the geography of connectivity. While we tend to think of the internet alternatively in terms of reducing distance and enabling connections between places and peoples or as a facilitator of a shared cyber-space (Malecki, 2002), both imaginations fail to fully capture the very powerful way that the internet has been employed in the Kenyan BPO and software industries.

Fibre optic cables are neither solely material links between places nor facilitators of a transcendental geography. Rather their roll-out should be understood within a geography of representation in which people use both technical skills and representational skills to shape their online representations. Whether or not the internet will allow Kenyan and other African entrepreneurs to successfully change the perceptions that foreigners hold of their countries is uncertain, as both the 419 scammers of West Africa and the reproduced 'Otherings' of tourism and government websites demonstrate . The internet opens up new potentials for representation, but these opportunities are contested.

\section{CONCLUSIONS}

Firms have always had to adapt to technological changes in order to remain competitive and so this paper's focus on Kenya's ICT sector offers a unique opportunity to ask both how the cables are altering economic relationships, and how they are changing experienced and imagined economic geographies. The paper has demonstrated that the arrival of fibre-optic cables into East Africa generated much initial 'buzz' within, and about, the ICT industry, and allowed for a radical reimagining of the potentials for economic development. Expectations for radical change were seen in government policies and statements, media reports, and in the plans and aspirations of companies in the sector. In all of these cases there are hopes that changes in connectivity would ultimately lead to significant economic transformations.

Despite the fact that this paper is based on non-representative samples, we can see that within Kenya's BPO sector, there were a diverse range of creative and innovative practices (and possibilities) that have so far been given little space in office government visions, documents, plans, statements and policies in place immediately after the arrival of fibre-optic connectivity. Rather than highlight some of the unique work being carried out in Kenya, many of the official plans sought to emulate a model of low-end BPO work performed elsewhere in the world and compete largely on price. These plans were thus enacting Singh and Gurumurthy's (2006) worries that the concept of an information society will simply encourage a shifting of low-end work to parts of the world with the lowest wages and weakest regulatory environments. More broadly, it is possible that such plans simply reflect older observations that technical advances have always benefitted cores over peripheries (e.g. Prebisch, 1972).

Although these plans are progressing, and the number of call and contact centres in Kenya is increasing, we have seen that many people and firms in the sector began to forge significantly different paths. Nairobi is home to thousands of developers and designers that 
are starting companies, building new products, and performing a diverse range of information processing services. Some of this work is carried out by start-ups attempting to build a reputation or brand, while other work is characterised by informal, freelance, unfixed practices using platforms like Guru.com and Elance.com. It is ultimately up to further research to get a better sense of how significant these practices are. Future work could ask questions like:

- Are path-dependencies being laid (due to either rules or untraded interdependencies) that may hinder the development of high-tech start-ups?

- How can Kenyan firms better take advantage of upgraded value chain positions?

- Whose interests do these reconfigurations of the Kenyan economy serve?

- How do these alternate practices tie into broader processes of economic development in Kenya?

Irrespective of the actual effects of the cables within Kenya's BPO sector, the discourse of connection was a powerful force driving much of the work performed in the sector. This is not to say the hyperbole about the arrival of the cables is not problematic. We have seen that these narratives can oversimplify economic relationships, communication and connectivity; that connectivity is presented as a binary in which distance becomes irrelevant and Kenya moves into some sort of imagined global village; that new connections are presented as a panacea for perceived deficiencies in development; and that many imagine that the arrival of fibre-optic connectivity will bring Kenya into an imagined 'global village.' The way in which we frame the intersections between economic development and ICTs matter, and sometimes can lead to unrealistic expectations, and a lack of focus on any potential harmful effects of the creative destruction that might be accelerated by Kenya's changing communications ecosystem. However, within the contexts of the Kenyan BPO sector, it is also worth noting that these same unrealistic discourses being circulated and re-circulated are normative concepts that drove a distinct sense of optimism, hype and hope. Despite frequent power cuts, distance from markets, and various other competitive disadvantages that Kenyan firms face, the narrative about the arrival of the cables translated into an unbridled optimism that was seen in almost all of the interviews, media coverage and development plans related to the BPO sector.

In other words, it is not just cost, speed, and the ability to access information and communicate that are having a transformative effect, but also a powerful unbridled optimism that drove, and allowed for a reimagining of policies, practices, and expectations. The case of the arrival of fibre-optic cables and Kenya's BPO sector provide a fascinating case of how expectations about the development potentials of broadband internet matched up to observable effects. However, we now need further sustained research that asks who the winners and losers will be. If internet use, the capacity to access and use the requisite hardware and software, and even electricity supplies, ${ }^{12}$ remain highly concentrated in only certain parts of the country and amongst certain segments of the population, ${ }^{13}$ it is unlikely

12 Just under 29\% of Kenyan households are connected to the electricity grid (KIPPRA 2010: 21).

13 For example, the vast majority of African Internet users are male (McCormick, 2002).

Whilst Thioune (2003: 29) has found that a majority of women feel that these "instruments are not made for them.”

The Electronic Journal of Information Systems in Developing Countries www.ejisdc.org 
that the benefits of Kenya's BPO sector will be broadly accrued. Within the sector, we also need to ask how this new reliance on flexible labour, highly volatile contracts and global body shopping will affect the Kenyan workforce: explore if the sector lives up to the expectations that have been placed on it; and how Kenyan firms can better position themselves in global value chains; and, ultimately interrogate what does the growth of Kenya's BPO reveals about the potentials of this type of growth of this type of work elsewhere in the South.

The case of the BPO sector in Kenya shows us that broadband internet is both the subject and the shaper of many promises and that it is often a prerequisite rather than a determinant of economic growth. As such, much more research and focus is needed on the ways in which the internet will influence Kenya's human development goals and the role that the BPO sector will play in those plans.

\section{REFERENCES}

Achebe, C. (1977) An Image of Africa, The Massachusetts Review, 18, 4, 782-794.

Ajulu, R. (2001) Thabo Mbeki's African Renaissance in a Globalizing World Economy: The Struggle for the Soul of the Continent, Review of African Political Economy 87, 2742.

Akerlof G. and Shiller, R. (2009) Animal Spirits. How Human Psychology Drives the Economy and Why it Matters for Global Capitalism, Princeton University Press, New Jersey.

Allen, C. (1995) Understanding African Politics, Review of African Political Economy, 22.

Asiedu, E. (2002) On the Determinants of Foreign Direct Investment to Developing Countries: Is Africa Different? World Development 30, 1, 107-119.

Bathelt, H., Malmberg, A. and Maskell, P. (2004) Clusters and Knowledge: Local Buzz, Global Pipelines and the Process of Knowledge Creation, Progress in Human Geography 28, 1, 31-57.

Bayart, J-F. (2000) Africa in the World: A History of Extraversion, African Affairs, 99, 217267.

Binswange, H.P. and von Braun, J. (1991) Technological Change and Commercialization in Agriculture. The Effect on the Poor, World Bank Research Observer, 6, 1, 57-80.

Bonsu, S.K. (2009) Colonial Images in Global Times: Consumer Interpretations of Africa and Africans in Advertising, Consumption Markets \& Culture, 12, 1, 1-25.

Caliskan, K. and Callon, M. (2009) Economization, Part 1: Shifting Attention from the Economy Towards Processes of Economization, Economy and Society, 38, 3, 369398.

Caliskan, K. and Callon, M. (2010) Economization, Part 2: A Research Programme for the Study of Markets, Economy and Society, 39, 1, 1-32.

Callon, M., Millo, Y. and Muniesa, F. (2007) Market Devices, Blackwell, Oxford.

Cesaire, A. (1997) Discourse on Colonialism, in: Chukwudi Eze, E. (Ed.) African Philosophy: An Anthology, Wiley-Blackwell, New York.

China Daily (2010) Major ICT initiatives connect Kenya to the world, China Daily, May 3, 2010. http://www.chinadaily.com.cn/2009market/kenya2.pdf

Cline-cole, R. and Powell, M.. (2004) ICTs, 'Virtual Colonisation' \& Political Economy, Review of African Political Economy, 31, 99, 5-9.

Comaroff, J.L. and Comaroff, J. (2009) Ethnicity, Inc. University of Chicago Press, Chicago

Cooper, F. (2002) African Since 1940: The Past of the Present (New Approaches to African History, Cambridge University Press, Cambridge. 
de Meza, D. and Southey, C. (1996) The Borrower's Curse: Optimism, Finance and Entrepreneurship, The Economic Journal 106, 435, 375-386.

Etta, F. E. and Parvyn-Wamahiu, S. (2003) Information and Communication Technologies for Development in Africa: The Experience with Community Telecentres, IDRC, Ottawa.

Fair, J E. (1993) War, Famine, and Poverty: Race in the Construction of Africa's Media Image, Journal of Communication Inquiry, 17, 5, 5-22.

Florida, R. (2002) The Economic Geography of Talent. Annals of the American Association of Geographers 92, 4, 743-755.

Fürsich E and Robins, M.B. (2002) Africa.com: The Self-Representation of sub-Saharan Nations on the World Wide Web. Critical Studies in Media Communication, 19, 2, 190-211.

Galbraith, J.K. (1954) The Great Crash: 1929, Houghton Mifflin Co, Boston, MA.

Graham, M. (2008) Warped Geographies of Development: The Internet and Theories of Economic Development, Geography Compass, 2, 3, 771-789.

Graham, M. (2011) Time Machines and Virtual Portals: The Spatialities of the Digital Divide, Progress in Development Studies, 11, 3, 211-227.

Graham, M. (2013) Geography/Internet: Ethereal Alternate Dimensions of Cyberspace or Grounded Augmented Realities? The Geographical Journal (in press)

Heeks, R. (2007) Using Competitive Advantage Theory to Analyze IT Sectors in Developing Countries: A Software Industry Case Analysis, Information Technologies and International Development 3, 3, 5-34.

Heeks, R. \& Kanashiro, L.L. (2009) Remoteness, Exclusion and Telecentres in Mountain Regions: Analysing ICT-Based "Information Chains”, Development Informatics Working Paper Series 38.

Heeks, R.B. and Kenny, C. (2002) The Economics of ICTs and Global Inequality: Convergence or Divergence for Developing Countries? Development Informatics Working Paper Series, University of Manchester, Manchester.

Hersman, E. (2011) iHub: 3000 Members and 1yr Old. White African March 1, 2011 http://whiteafrican.com/2011/03/11/ihub-3000-members-and-1yr-old/

Kenya ICT Board. (2010) Presentation to British Chamber of Commerce http://www.kobauk.com\%2Fwordpress\%2Fpresentations\%2FEXPO-ICT-Board-Presentation-01-Oct2010.pdf.

Kenya ICT Board. (2012) ICT Innovators get a boost of over a 100 million from Government, http://www.ict.go.ke/index.php?option=com_content\&task=blogsection \&id=12\&Itemid=399

Kenya Ministry of Trade. (2012) http://www.trade.go.ke

KIPPRA (2010) A Comprehensive Study and Analysis on Energy Consumption Patterns in Kenya, Kenya Institute for Public Policy Research and Analysis http://www.cofek.co.ke/ ERCStudy_ExecSummary_02082010.pdf

Lovejoy, P.E. (2011) Transformations in Slavery: A History of Slavery in Africa, Cambridge University Press, Cambridge.

Malecki, E.J. (2002) The Economic Geography of the Internet's Infrastructure, Economic Geography 78, 4, 399-424.

Mark, O. (2011) Nation's Technopolis Dream Gets a Boost From European, Asian Firms. Business Daily, 22 February. http://allafrica.com/stories/201102220175.html

Mark, O. (2012) Why Kenya is Country to Watch for Ground-Breaking Innovations in ICT Sector Business Daily $26^{\text {th }}$ February. http://www.businessdailyafrica.com/Corporate +News/Why+Kenya+is+country+to+watch+for+innovations+in+ICT+sector+//539550/1335424/-/af0mk7z/-/index.html 
Marker, P., McNamara, K. and Wallace, L. (2002) The Significance of Information and Communication Technologies for Reducing Poverty, DFID, London.

Markham, A. (1998) Life Online: Researching Real Experience in Virtual Space, Altamira Press, Berkeley, CA.

Martin, R and Sunley, P. (2003) Deconstructing 'Clusters': Chaotic Concept or Policy Panacea?, Journal of Economic Geography, 3, 5-35.

McCormick, D. (1999), African Enterprise Clusters and Industrialization: Theory and Reality, World Development 27, 9, 1531-1551.

McCormick, P. K. (2002) Internet Access in Africa: A Critical Review of Public Policy Issues, Comparative Studies of South Asia, Africa and the Middle East, 22, 1, 140144.

Mudimbe, V. Y. (1988) The Invention of Africa, Indiana University Press, Bloomington.

Muli, E. (2010) Malili e-town: Kenya Government About To Invite Tenders Investment News Kenya, http://www.investmentnewskenya.com/malili-e-town-kenya-governmentabout-to-invite-tenders-2/

Murphy, J.T. (2007) The Challenge of Upgrading in African Industries: Socio-spatial Factors and the Urban Environment in Mwanza, Tanzania World Development 35, 10, 17541778.

Ndemo, B. (2010) Malili Multi-Use Technopolis- the Concept Presentation to KICTANET, University of Nairobi, http://www.slideshare.net/blongwe/malili-technopolis-conceptpaper

Nworah, U. (2006) Rebranding Nigeria: Critical Perspectives On The Heart Of Africa Image Project http://www.brandchannel.com/images/papers/40_Rebranding\%20Nigeria\%20\%20Critical\%20Perspectives.pdf

OECD. (2006). OECD Broadband Statistics to December 2006 http://www.oecd.org/document/7/0,3746,en_2649_34225_38446855_1_1_1_1,00.html

Omondi, G. (2012) Kenya: BPO Firms Suffer from Worsening Job Losses in the West. Business Daily. $15^{\text {th }}$ of February, 2012. http://allafrica.com/stories/201202160548.html

Orgad, S. (2008) How Can Researchers Make Sense of the Issues Involved in Collecting and Interpreting Online and Offline Data? In: Markham, A. and Baym, N. (Eds.) Internet Inquiry: Conversations about Cethod, Sage, Los Angeles, 33-53.

Parmentier, J.L. and Stafford, E. (2010) SEACOM: Continuing its Commitment to East African Development. White paper presented at the SubOptic 2010 conference. http://www.suboptic.org/App/Viewdocument.aspx?id=605

Prebisch, R. (1972) International Economics and Development, Academic Press, New York. Republic of Kenya (2007a) Vision 2030: A Globally Competitive and Prosperous Kenya Government of Kenya, Nairobi.

Republic of Kenya (2007b) Vision 2030: The Popular Version Government of Kenya, Nairobi.

Singh, P. J. and Gurumurthy, A. (2006) Political Economy of the Information Society: A Southern View, IT for Change, Bangalore. http://www.itforchange.net/sites/default/ files/ITfC/Full\%20paper.pdf

Storper, M. and Venebles, A.J. (2004) Buzz: Face-to-Face Contact and the Urban Economy, Journal of Economic Geography, 4, 351-370.

Sveningsson, M. (2008) How do Various Notions of Privacy Influence Decisions in Qualitative Internet Research? In: Markham, A. and Baym, N. (Eds.) Internet Inquiry: Dialogue among Researchers, Sage, Los Angeles.

Thioune, R.M. (2003) Information and Communication Technologies for Development in Africa (Vol. 1: Opportunities and Challenges for Community Development) IDRC, Ottawa. 
Waema, T. (2005) A Brief History of the Development of an ICT Policy in Kenya, in: Etta, F. and Elder, L. (Eds.) At the Crossroads: ICT Policy Making in East Africa, East African Educational Publishers, Nairobi.

Wafula, P. (2012) Board Plans 500 New Firms by 2017 to Push Kenya to Top 10 ICT Hubs. Daily Nation. April 8 ${ }^{\text {th }}$, 2012. http://www.nation.co.ke/business/news//1006/1382618/-/item/1/-/u8t3y3z/-/index.html

Wainaina, B. (2005) How to Write about Africa. Granta 92: The View from Africa http://www.granta.com/Archive/92/How-to-Write-about-Africa/Page-1

Wellman, B. and Haythornthwaite, C. (2002) The Internet in Everyday Life, Blackwell, Oxford.

World Bank. (2011) Enterprises Surveys, http://data.worldbank.org/indicator/IC.FRM.OUTG.ZS

Ya'u, Y.Z. (2004) The New Imperialism \& Africa in the Global Electronic Village, Review of African Political Economy, 31, 99, 11-29. 